\title{
SPATIO-TEMPORAL ANALYSIS OF THE PRACTICE OF URBAN AGRICULTURE IN LAGOS METROPOLIS AND THE IMPLICATIONS FOR URBAN PLANNING
}

\author{
Dauda Rotimi AWONIRAN \\ Department of Remote Sensing and Geoscience Information System, \\ Federal University of Technology, Akure, Nigeria, e-mail: awonirandaud2@gmail.com \\ Omotayo Ben OLUGBAMILA* \\ Department of Urban and Regional Planning, Obafemi Awolowo University, Ile-Ife, Nigeria, \\ e-mail: olugbamilao@gmail.com \\ Emmanuel Olufemi OMISORE \\ Department of Urban and Regional Planning, Obafemi Awolowo University, Ile-Ife, Nigeria, \\ e-mail: femsor3@gmail.com
}

Citation: Awoniran, D.R., Olugbamila, O.B., Omisore, E.O., (2020). Spatio-Temporal Analysis of the Practice of Urban Agriculture in Lagos Metropolis and the Implications for Urban Planning. Analele Universitătii din Oradea, Seria Geografie, 30(1), 76-87. https://doi.org/10.30892/auog.301109-819

\begin{abstract}
The study examined the practice of urban agriculture and changes in agricultural land use in the last three decades, and assess the implications of these changes for urban planning in Lagos Metropolis, a mega city in Sub-Saharan Africa. Multistage sampling technique was used to collect primary data from four Local Government Areas. Landsat Thematic Mapper (TM) image of 1986, Landsat Enhanced Thematic Mapper Plus (ETM+) image of 2000, Landsat 8 of 2016 as well as Google Earth image of 2015 was processed using ArcGIS 10.3.1, IDRISI and ERDAS Imagine 9.2 software. An inventory of the spatial extent, the rate of change and the pattern of conversion of urban farmlands to other land uses over the years in consideration were also carried out. Findings from the study showed that variation exists in the practice of urban agriculture among the sampled LGAs in terms of gender $\left(\chi^{2}=33.108, p<0.001\right)$, age distribution $\left(\chi^{2}=37.744, p<0.001\right)$, marital status $\left(\chi^{2}=26.051, p<0.002\right)$, level of education $\left(\chi^{2}=28.172, p<0.001\right)$ and farming experience $\left(\chi^{2}=52.837, \mathrm{p}<0.001\right)$. Cultivated lands decreased by $28.70 \%$ between 1986 and 2000 and by $19.25 \%$ between 2000 and 2016. So also between 1986 and 2000, 89.48\% of urban farmlands had been converted to other land uses, and also between 2000 and 2016, 75.64\% had been converted to other land uses. The results of this study gives an indication that food security is under threat in Lagos Metropolis as the land available to urban farmers continue to shrink. The study therefore recommends a new planning approach that will accommodate sustainable urban agriculture.
\end{abstract}

Key words: urban agriculture, conversion, change detection, food security

$$
* \quad * \quad * \quad * \quad * \quad *
$$




\section{INTRODUCTION}

Food production in and around cities is an integral part of the urban fabric in much of the developing world. In these regions, urban and peri-urban agriculture (UPA) plays an important role in diversifying urban diets and providing environmental services in urban and peri-urban areas (Sy et al., 2014). Urban agriculture is a rather discreet but cosmopolitan phenomenon, resulting from the quest by urban households to enhance their means of livelihood. Discreet because it is often practised in inconspicuous vacant lands or open spaces, cosmopolitan because it is practised in every city of both developed and developing countries.

Urban agriculture have been variously defined by researchers as any agricultural enterprise within or on the fringes of a town, city, or metropolis that grows, processes, and distributes food and non-food products (Moustier, 1999; Mougeout, 2006; Lovell, 2010). Smit et al., (2001) referred to urban agriculture as 'metropolitan-intensive agriculture' and comprehensively defined it as an industry that produces, processes, and market food, fuel, and other outputs, largely in response to the daily demand of consumers within a town, city, or metropolis, on many types of privately and publicly held land and water bodies found throughout intra-urban and peri-urban areas.Within the context of this study, urban agriculture is defined as agricultural activities involving the growing and marketing of different types of crops and animals, either on a subsistence or commercial scale, within or at the periphery of a town, city or metropolitan area.

Inherent in all these definitions is the fact that urban agriculture is a spatial attribute of every metropolitan city and the fact that urban agriculture contributes significantly to the socioeconomic development of towns and cities throughout the world. Urban agriculture has benefits as well as risks to the environment and health. These benefits and risks have been the focus of many researchers (Mougeot, 2000; Afrane et al., 2002; Faraqui et al., 2004; Veenhuizen, 2006). However, UA is a phenomenon that is prone to change. Indeed, due to the often transitory nature of urban agriculture, it is often considered to be a new phenomenon. The space and resources available to UA practitioners vary both quantitatively and qualitatively over short periods of time, as has been noted by some researchers (Losada et al., 1998; Arturo and Simon, 2003; Foeken, 2012). An in-depth understanding of the spatial and temporal dynamics of urban agriculture is therefore necessary to put the practice in its proper context.

Urban agriculture can occur on many types of private or public land or water bodies both within and on the edges of cities, taking on many forms depending on the local context to yield an array of land- water- and air-based biodiversity, contributing to the food security, health, livelihood and habitat of all living beings and systems. It can be a transient or permanent feature in both developed and developing nations (Rabiul and Chamhuri, 2012). Although many farms changed their location over time, other open areas- usually those unsuitable for housing or other developments- have been under continuous cropping for the past 20 - 50 years as reported from West and East Africa (Drechsel and Dongus, 2010). Urban agriculture contributes to a wide variety of urban issues and is increasingly being accepted and used as a tool in sustainable city development. Currently the challenge is its integration into city planning and facilitation of its multiple benefits for urban inhabitants (Veenhuizen, 2006; Omisore and Olaleye, 2011). To this extent many studies have been conducted on urban agriculture and urban food security providing data on the presence and persistence of urban agriculture in cities and its importance for urban food security and income generation for the urban poor (Veenhuizen and Danso, 2007; Nsangu and Redwood, 2009; Ajadi et al., 2011; Akinmoladun and Adejumo, 2011). A number of these studies have focused on urban agriculture as a livelihood activity and have provided important insights (Duressa, 2007; Aina et al., 2012). This present study therefore, examined the practice of urban agriculture, in Lagos Metropolis, assess the spatial and temporal variability of agricultural land use and the implication of these for urban planning.

\section{STUDY AREA}

Lagos State is geographically positioned between Longitude $2^{0} 42^{\prime}$ and $4^{0} 20^{\prime}$ East and Latitude $6^{0} 22^{\prime}$ and $6^{\circ} 42^{\prime}$ North. It is bounded on the West by the Republic of Benin, in the North and 
East by Ogun State and in the South by the Atlantic Ocean. It has a population of over 10 million people (NPC, 2007), and a population density of 5,926 persons per square kilometer (Komolafe et al., 2014). Lagos metropolitan area is one of the most rapidly urbanizing areas in the world and as such has been designated the second megacity in Africa. The metropolitan area comprises of seventeen out of the twenty Local Government Councils which make up the State. These include: Lagos Island, Eti-Osa, Lagos Mainland, Surulere, Ikeja, Ajeromilfelodun, Amuwo-Odofin, Alimosho, Apapa, Ojo, Somolu, Kosofe, Mushin, Oshodi-Isolo, Agege and Ikorodu (Akinmoladun and Adejumo, 2011) (figure 1).

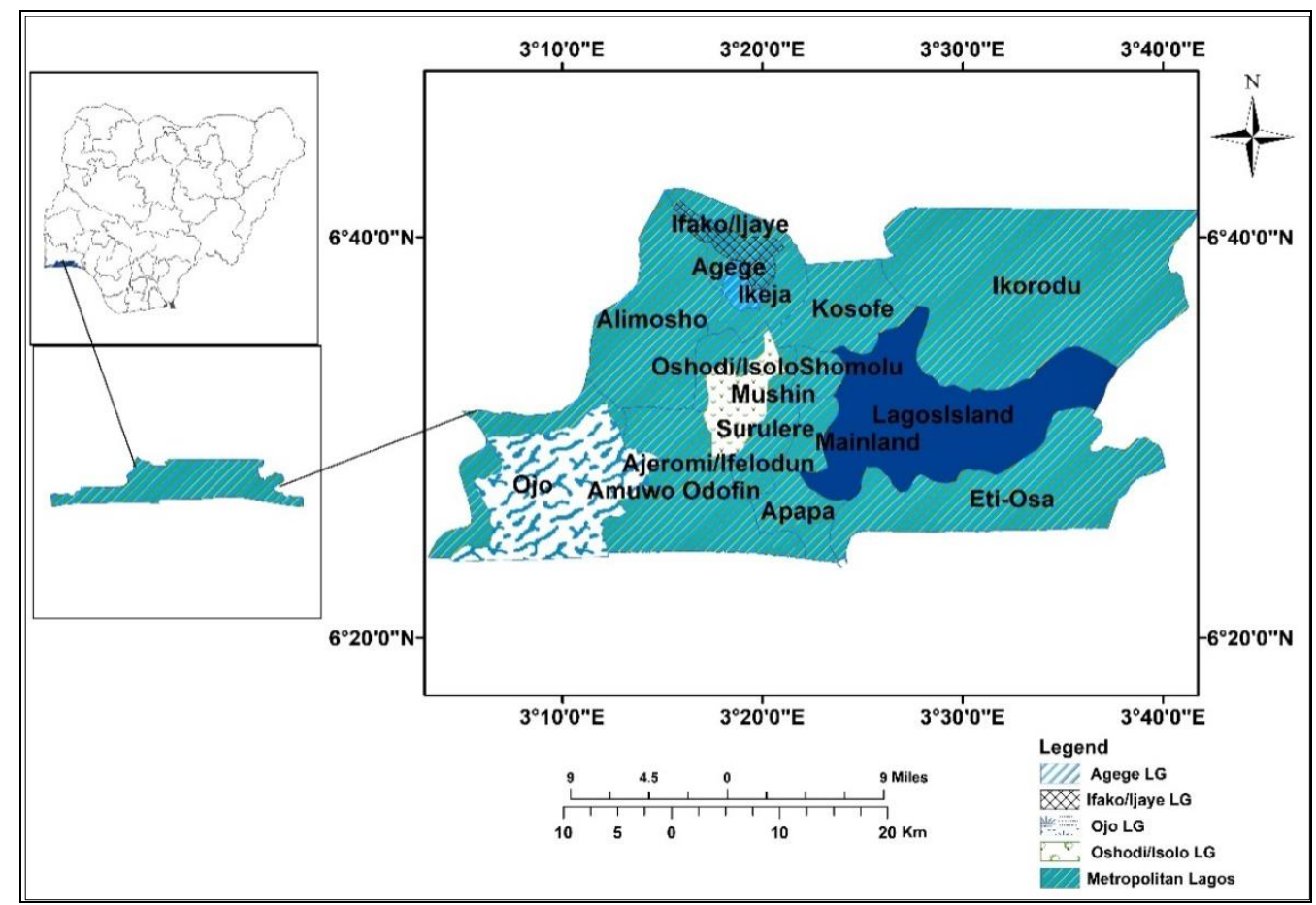

Figure 1. Map of the study area

(Source: Authors' GIS data procesessing 2018)

The state is located within the sub-equatorial zone, which is characterized by rainfall throughout the year with two maxima (May to July and September to October). December and January have very little rain, and the annual rainfall is between 1500 to $2000 \mathrm{~mm}$. The effective temperature (ET) is between $32^{\circ} \mathrm{C}$ and $36^{\circ} \mathrm{C}$. However, the highest diurnal range of temperature in the dry season (mid -November to mid-March) is $20^{\circ} \mathrm{C}$ while the mean range is about $10^{\circ} \mathrm{C}$ during the warm and wet season (May to October). The highest air temperature occurs in April/May and the lowest occurs in December through February. The mean annual temperature is about $27^{\circ} \mathrm{C}$ while the annual range does not exceed $6^{\circ} \mathrm{C}$ (Ekanade, 1985). It lies within the rainforest belt dry lowland rainforest.

The vegetation of the region is swamp and marsh forest, part of which had given way to the construction of houses, markets and other infrastructure. Tree species here consist of typical colonizer or invaded species. These are plants with numerous and easily dispersed seeds and capacity for fast and vigorous establishment in cleared or open location. The river channels are characterized by vegetation of the wet southern segment of the rainforest belt. The characteristic vegetation include tall trees like Tarriefautilis, Geophilasp., epiphytic ferns (placycerinasp.), Tuchomanessp. Nephrolepissp. Mosses and Lierworts (Ogunbajo, 2005). 


\section{MATERIALS AND METHODS}

Landsat Thematic Mapper (TM) (r191p055/56), acquired on $24^{\text {th }}$ December, 1986, Landsat Enhanced Thematic Mapper Plus (ETM+) (r191p055/56), acquired on $6{ }^{\text {th }}$ February, 2000, Landsat 8 (r191p055), acquired on $18^{\text {th }}$ December, 2016 were obtained from the United States Geological Survey (USGS) website, as well as Google Earth image of 2015, which was used for groundtruthing.

Based on the information obtained from satellite imagery in combination with the list of registered urban farmers obtained from the Lagos State Agricultural Development Authority, urban farms were randomly selected for enumeration. Target groups for this study were urban crop farmers in Lagos State. Four local governments councils (figure 2) were purposively selected out of the seventeen local government councils that make up the Lagos Metropolitan Area. Subsequently urban farmers in the local government councils were selected using simple random technique. A total of 526 registered urban farmers in Agege LG, 925 in Ifako-Ijaye LG, 829 in Oshodi-Isolo and 569 in Ojo LG were obtained based on the information collected from the Lagos State Agricultural Development Programme (LSADP). Ten percent of the registered urban farmers from each local government council were randomly selected. A preliminary survey was carried out to identify, delineate and locate potential farm sites for the study. The survey was carried out using the high resolution Google Earth Map and a handheld Global Positioning System (GPS) between May and September 2015.

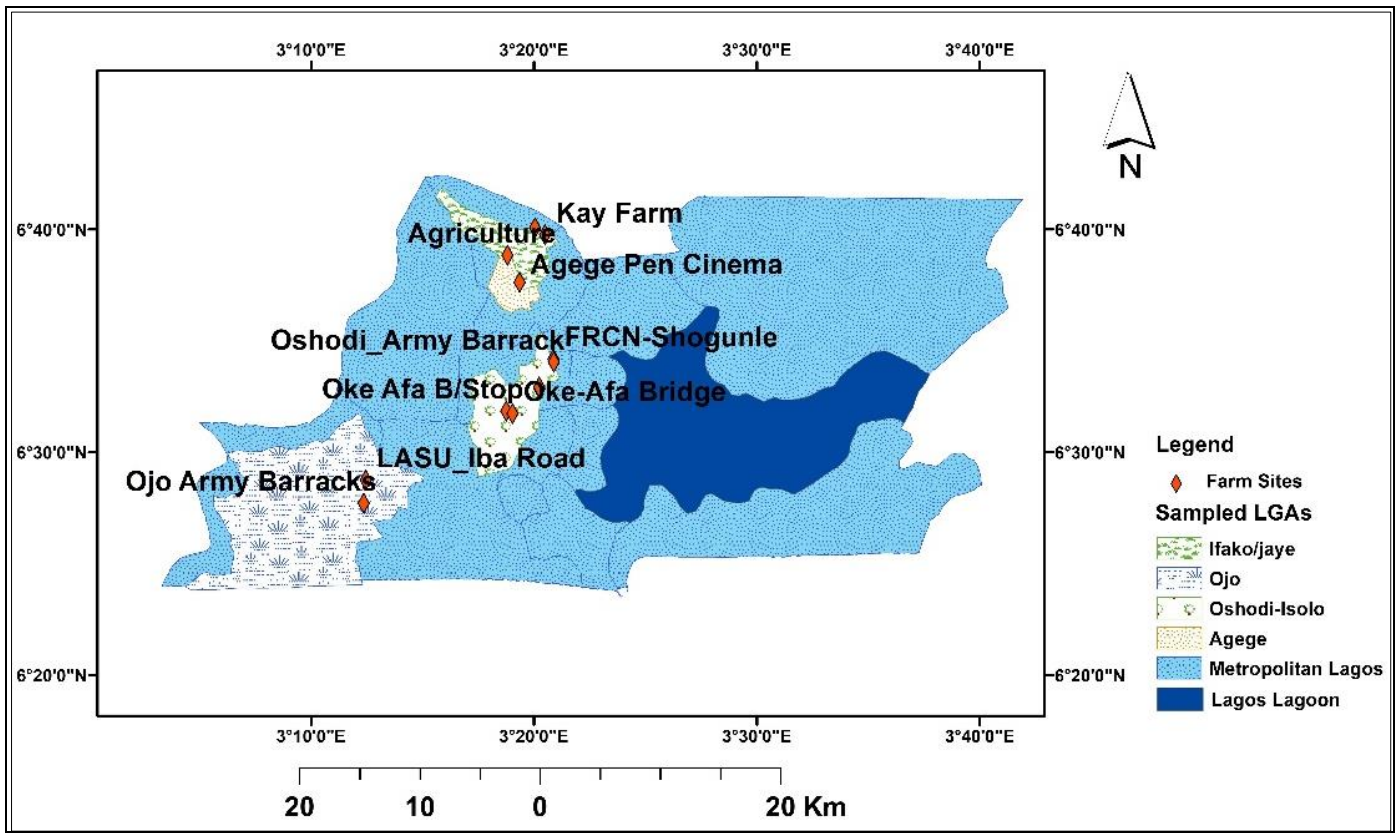

Figure 2. Map showing the locations of urban farms in the selected LGAs

(Source: Authors' GIS data procesessing 2018)

The Landsat images were pre-processed to correct them for spectral variation resulting from sensor differences before the study area was extracted from each dataset. False colour composite (FCC) was created using near-infrared, red and green bands of each of the images. The selection of band combination was done to enhance our ability to clearly distinguish vegetation types from urban land use (Enaruvbe and Atedhor 2015).

A combination of image composite, supervised image classification, and field survey were used for image analysis. The land cover categories are farmlands, built up, wetlands, open space, light forest, shrub and water body. The ERDAS Image Software Accuracy Assessment Utility was 
used to perform an accuracy assessment for the classified images. Thus for the 1986 land use/land cover classification the overall accuracy of $64.29 \%$ and an overall kappa statistics of 0.58 was generated. On the other hand for both the 2000 and 2016 land use/land cover the overall accuracy was $85.71 \%$ and overall kappa statistics was 0.82 . The Kappa coefficient expresses the proportionate reduction in error generated by a classification process compared with the error of a completely random classification. The rate of environmental change was determined by computing the percent average rate of change using equation (1) thus:

$$
\left[\frac{\left(\frac{d}{t_{1}}\right) * 100}{y_{2}-y_{1}}\right](1)
$$

Where $\mathrm{d}$ is the difference in the value of area covered by a land cover category at the initial time point and final time point while $\mathrm{t} 1$ is the value of the area covered by a land cover category in the initial time point and $y_{1}$ and $y_{2}$ are base year and final year respectively (Enaruvbe and Atedhor, 2015).

\section{Change Detection Analysis}

The point by point analysis involved the actual topological overlay of the various classified land use/land cover maps generated within the IDRRISI software, to produce change maps (Change Detection Exercise). This was done to generate the nature, location and magnitude of the changes in urban farmlands. In addition, the topological map overlay resulted in the generation of a twodimensional change matrix within the GIS environment. This two-dimensional matrix shows the nature of the land use and land cover changes for two given sets of years.

\section{RESULTS AND DISCUSSION \\ Socio-Economic Profile of Respondents}

As presented in table 1 , the practice of urban agriculture cut across both male and female gender, thus 50.6\%; of the urban farmers in Metropolitan Lagos were female while 49.4 were male. Similar findings have been reported by Smit et al., (2001) and Sy et al., (2014), Smit et al argued that because feeding the family is the responsibility of the woman she is more immediately conscious of food insecurity and malnutrition as well as food quality, and is typically the first to seek opportunities to augment the food supply. It was also revealed that majority $(76 \%)$ of the farmers were married, thus it is observed that most urban farmers in Metropolitan Lagos engaged in agricultural practice as a means of augmenting their families' food intake. The table also indicates that most of the urban farmers $(54.8 \%)$ had primary education. Perhaps the low level of education of the farmers may be a reflection of the rudimentary and subsistence nature of their farming activities, which may however affect the adoption of new technology and innovation as noted by Salau and Attah (2012).

Bellwood-Howard et al., (2015) made similar observation in their study of urban farmers in Ouagadougou (Burkina Faso) and Tamale (Ghana) where they reported that $62 \%$ of 1,056 surveyed adults have not received any formal education.

Furthermore, $44.9 \%$ of the farmers were within 31-45 years of age, which implies that the urban farmers were within the economically active age. Meanwhile the mean household size of the farmers was 6 person, which fairly agree with that of Duressa (2007) who reported an average household size of 7 members in Adis Ababa, Ethiopia. The study however, showed that variation exists in the practice of agriculture among the sampled Local Governments in terms of gender $\left(\chi^{2}=\right.$ 33.108, $\mathrm{P}=0.000)$, age distribution $\left(\chi^{2}=37.744, \mathrm{P}=0.000\right)$, marital status $\left(\chi^{2}=26.051, \mathrm{P}=0.002\right)$, level of education $\left(\chi^{2}=28.172, \mathrm{P}=0.001\right)$ and farming experience $\left(\chi^{2}=52.837, \mathrm{P}=0.000\right)$. 
Table 1. Socio-Economic Characteristics of farmers (Data source: Author's Field work, 2018)

\begin{tabular}{|l|l|l|}
\hline Characteristics & Frequency & Percentage (\%) \\
\hline Gender & & \\
Male & 130 & 50.6 \\
Female & 133 & 49.4 \\
Marital Status & 19 & 7.2 \\
Single & 200 & 76.0 \\
Married & 39 & 14.8 \\
Widowed & 5 & 1.9 \\
Divorced & & \\
Education Level & 25 & 9.5 \\
No Formal Education & 144 & 54.8 \\
Primary Education & 82 & 31.2 \\
Secondary Education & 12 & 4.6 \\
Tertiary Education & & \\
Age Distribution & 23 & 8.7 \\
16-30 & 118 & 44.9 \\
31-45 & 108 & 41.1 \\
$46-60$ & 14 & 5.3 \\
Above 60 & & \\
1-5 & 119 & 45.2 \\
6-10 & 138 & 52.5 \\
$11-15$ & 6 & 2.3 \\
Household size & & \\
Farming Experience (Years) 11 to 20 & 56 & 21.3 \\
21 to 30 & 103 & 39 \\
above 30 & 79 & 30 \\
\hline
\end{tabular}

\section{Spatial Extent and Rate of Change in Agricultural Land Use (1986, 2000 and 2016)}

As shown in table 2, the entire study area covered 163,343.68 ha, in 1986, cultivated lands which is the focus of this study, constituted 20,654.40 ha (12.64\%), and in 2000 it constituted $14,727.18$ ha $(9.02 \%)$, while in 2016 it occupied $11,924.56$ ha $(7.30 \%)$ of the study area. Thus, it could be observed that between 1986 and 2000 cultivated lands decreased by 5,927.22 ha (28.70\%) and by $2,843.32$ ha (19.25\%) between 2000 and 2016. Although between 1986 and 2000 other land use categories such as open space, shrub and light forest decreased by 4,299.52 ha (16.28\%), $6,736.48$ ha $(23.52 \%)$ and $6,104.66$ ha $(25.46 \%)$ respectively, the rate of decline of cultivation was the highest. However, between 2000 and 2016 the rate of decrease of cultivated lands has slowed down to $2,843.32$ ha $(19.25 \%$ ), while other categories of land use such as water body, open space, shrub and light forest decreased by $6,354.68$ ha (18.43\%) 8,733.23 ha (39.44\%), 15,964.37 ha $(72.90 \%)$ and $11,396.32$ ha $(63.64 \%)$ respectively. On the other hand, built up increased by as much as $40,068.2$ ha (103.29\%), while wetland increased by $5,031.01$ ha $(37.11 \%)$.

It should also be noted that between 1986 and 2000 cultivation had the highest annual rate of decrease of $2.05 \%$ compared to open space, shrub and light forest which had $1.16 \%, 1.68 \%$ and $1.82 \%$ annual rates of decrease. Also, within this period water body, built up and wetland increased at the average rates of $0.78 \%, 2.58 \%$ and $16.24 \%$ per annum. On the other hand between 2000 and 2016 (table 3) the decline in cultivation had slowed down to an average rate of $1.20 \%$ per annum, while water body, open space, shrub and light forest decreased at the average rates of $1.15 \%, 2.47 \%$, $4.56 \%$ and $3.98 \%$ respectively. However, between 2000 and 2016 built up and wetland increased at the average rates of $6.46 \%$, and $2.32 \%$ per annum. Perhaps, the slowdown in the decline of cultivated lands may be attributed to the nascent result of the urban greening programme of the Lagos State Government which had begun to yield results, as it encourages horticulture and landscaping. A journey through the stretch of Agege-Aiport-Oshodi road and Oshodi-Oworonsoki road enroute Third Mainland confirms these findings. 
Furthermore, the above spatial configuration of cultivated lands in the Lagos metropolis between 1986 and 2016 tends to support the findings by Adereti et al. (2010), in their study of urban agriculture in Ojo Local Government where it was reported that $12 \%$ of urban farmers in the study area had frequent displacement. Urban agriculture is therefore increasingly under pressure from other competing urban land uses, especially urban built up area which has continued to consume more and more lands at the expense of other land uses.

Table 2. Spatial extent and rate of change in land use/land cover from 1986 to 2000

(Data source: Author's image analysis, 2018)

\begin{tabular}{|c|c|c|c|c|c|c|c|c|}
\hline & \multicolumn{2}{|c|}{1986} & \multicolumn{2}{|c|}{2000} & \multicolumn{2}{|c|}{$\begin{array}{c}\text { Change between } 1986 \\
\& 2000\end{array}$} & \multicolumn{2}{|c|}{$\begin{array}{c}\text { Average Rate of } \\
\text { Change }\end{array}$} \\
\hline LULC & $\begin{array}{l}\text { Area } \\
\text { (ha) }\end{array}$ & $\begin{array}{c}\text { Area } \\
(\%)\end{array}$ & $\begin{array}{l}\text { Area } \\
\text { (ha) }\end{array}$ & $\begin{array}{c}\text { Area } \\
(\%)\end{array}$ & $\begin{array}{l}\text { Area } \\
\text { (ha) }\end{array}$ & $\begin{array}{c}\text { Area } \\
(\%)\end{array}$ & $\begin{array}{l}\text { Area } \\
\text { (ha) }\end{array}$ & $\begin{array}{c}\text { Area } \\
(\%)\end{array}$ \\
\hline Water body & $31,041.06$ & 19.00 & $34,418.79$ & 21.07 & 3377.73 & 10.88 & 241.27 & 0.78 \\
\hline Built up & $28,495.25$ & 17.45 & $38,782.77$ & 23.74 & $10,287.52$ & 36.10 & 734.82 & 2.58 \\
\hline Cultivation & $20,654.40$ & 12.64 & $14,727.18$ & 9.02 & $-5,927.22$ & -28.70 & -423.37 & -2.05 \\
\hline Open space & $26,404.54$ & 16.17 & $22,105.02$ & 13.53 & $-4,299.52$ & -16.28 & -307.11 & -1.16 \\
\hline Shrub & $28,637.36$ & 17.53 & $21,900.88$ & 13.41 & $-6,736.48$ & -23.52 & -481.18 & -1.68 \\
\hline Light forest & $23,972.98$ & 14.68 & $17,868.32$ & 10.94 & $-6,104.66$ & -25.46 & -436.05 & -1.82 \\
\hline Wetland & $4,138.09$ & 2.53 & $13,546.77$ & 8.29 & $9,408.68$ & 227.37 & 672.05 & 16.24 \\
\hline Total & $163,343.68$ & 100 & $163,349.73$ & 100 & - & - & - & - \\
\hline
\end{tabular}

*LULC- Land use/Land cover

Table 3. Spatial extent and rate of change in land use/land cover from 2000 to 2016

(Data source: Author's image analysis, 2018)

\begin{tabular}{|c|c|c|c|c|c|c|c|c|}
\hline \multirow[b]{2}{*}{ LULC } & \multicolumn{2}{|c|}{2000} & \multicolumn{2}{|c|}{2016} & \multicolumn{2}{|c|}{$\begin{array}{l}\text { Change between } \\
2000 \& 2016\end{array}$} & \multicolumn{2}{|c|}{$\begin{array}{c}\text { Average Rate of } \\
\text { Change }\end{array}$} \\
\hline & Area & Area & Area & Area & Area & Area & Area & Area \\
\hline & (ha) & $(\%)$ & (ha) & $(\%)$ & (ha) & $(\%)$ & (ha) & $(\%)$ \\
\hline Waterbody & $34,418.79$ & 21.07 & $28,120.06$ & 17.22 & $-6,354.68$ & -18.43 & -397.17 & -1.15 \\
\hline Built up & $38,782.77$ & 23.74 & $78,860.46$ & 48.28 & $40,068.2$ & 103.29 & $2,504.26$ & 6.46 \\
\hline Cultivation & $14,727.18$ & 9.02 & $11,924.56$ & 7.30 & $-2,843.32$ & -19.25 & 177.71 & 1.20 \\
\hline Open Space & $22,105.02$ & 13.53 & $13,410.41$ & 8.21 & $-8,733.23$ & -39.44 & -545.83 & -2.47 \\
\hline Shrub & $21,900.88$ & 13.41 & $5,933.96$ & 3.63 & $-15,964.37$ & -72.90 & -997.77 & -4.56 \\
\hline Light forest & $17,868.32$ & 10.94 & $6,511.58$ & 3.99 & $-11,396.32$ & -63.64 & -712.27 & -3.98 \\
\hline Wetland & $13,546.77$ & 8.29 & $18,588.68$ & 11.37 & $5,031.01$ & 37.11 & 314.44 & 2.32 \\
\hline Total & $163,349.72$ & 100 & $163,349.71$ & 100 & - & - & - & - \\
\hline
\end{tabular}

*LULC- Land use/Land cover

\section{Persistence, Gain and Loses in Agricultural Land use in Lagos Metropolis (1986-2016)}

Table 4 revealed that between 1986 and 2000 while only $14.75 \%$ of cultivated lands remained unchanged, as much as $89.48 \%$ of cultivated lands have been converted to other land uses such as water body, built up, light forest and wetland which has net gains of $9.81 \%, 26.53 \%, 34.17 \%$ and $69.45 \%$ respectively. Whereas, within this same period even though cultivated lands had a gain of $85.25 \%$, it suffered a net loss of $40.25 \%$.

Also, between 2000 and 2016 (table 5) while $30.09 \%$ of cultivated lands remained unchanged as much as $75.64 \%$ have been lost to other land uses. Within this period although cultivated lands had a gain of $69.91 \%$ it suffered a net loss of $23.50 \%$. In comparison to cultivated lands, between 2000 and $2016,96.31 \%$ of water body, $40.35 \%$ of built up, $20.19 \%$ of open space, $33.65 \%$ of shrub, $53.76 \%$ of light forest and $35.07 \%$ of wetland remained unchanged, while within these same period water body, built up, and wetland had a net gain of $22.40 \%, 50.82 \%$ and $27.12 \%$ respectively, open space, shrub and light forest had a net loss of $64.84 \%, 269.08 \%$ and $174.41 \%$ respectively. The inference that may be drawn from the preceding findings is the fact that while urban agriculture is being practiced consistently in Lagos metropolis, urban farmers are either being displaced by land speculators or by perennial flooding, and are being forced to abandon their farmlands, which are often on marginal lands. 
The pattern of distribution and fragmentation of cultivated lands between 1986 and 2016 is presented in figures 3a-c. More farmlands were present in 1986 compared with that of 2000 and 2016. However, while urban farmlands appeared extensive in 1986, they appeared more fragmented in 2000 and by 2016 they have been completely engulfed by built up and reduced to small patches. This observed spatial pattern of cultivated lands is an indication of the fact that the land available to urban farmers in Lagos Metropolitan area for the practice of urban agriculture has continue to shrink over the years, thereby hampering large scale production of crops and hence promoting only subsistence farming. The result presented above further revealed the dynamic and migratory nature of urban agriculture as has been noted by some researchers (Mougeout, 2000; Drechsel \& Dongus, 2010; Addo, 2010; Islam \& Siwar, 2012).

Veenhuizen \& Danso (2007) observed that the city is in a constant process of building and decay. Open spaces get built on and their formal or informal temporary users become evicted (as is regularly happening to many urban farmers); they are forced to find an alternative location or give up farming. Meanwhile, degenerated residential, office or industrial areas are demolished, creating new open spaces that may stay vacant for a long time until given a new use and the required investments become available. New roads and power lines are built, creating new vacant open spaces. Often, such newly created open spaces are gradually occupied by urban producers (informal occupation or temporary leases).

Table 4. Proportion of Agricultural Land use Gained and/or Lost between 1986 and 2000 (Data source: Author's image analysis, 2018)

\begin{tabular}{|c|c|c|c|c|c|c|c|c|c|c|}
\hline \multirow[t]{2}{*}{ LULC } & \multicolumn{2}{|c|}{$\begin{array}{c}\text { LULC in } 1986 \text { and } \\
\text { Unchanged in } \\
2000\end{array}$} & \multicolumn{2}{|c|}{$\begin{array}{l}\text { LULC in } 1986 \text { lost } \\
\text { to other LULC by } \\
2000\end{array}$} & \multicolumn{2}{|c|}{$\begin{array}{l}\text { LULC in } 1986 \\
\text { gained from other } \\
\text { LULC type by } 2000\end{array}$} & \multicolumn{2}{|c|}{$\begin{array}{c}\text { LULC in } 2000 \\
\text { (unchanged + gained) }\end{array}$} & \multicolumn{2}{|c|}{$\begin{array}{l}\text { Difference of (1986- } \\
\text { 2000) LULC gained-lost }\end{array}$} \\
\hline & $\mathrm{Ha}$ & $\%$ & $\mathrm{Ha}$ & $\%$ & $\mathrm{Ha}$ & $\%$ & $\mathrm{Ha}$ & $\%$ & $\mathrm{Ha}$ & $\%$ \\
\hline Water body & $26,557.35$ & 77.16 & $4,483.71$ & 14.44 & $7,861.44$ & 22.84 & $34,418.79$ & 100 & $+3,377.73$ & +9.81 \\
\hline Build up & $14,942.99$ & 38.53 & $13,552.26$ & 47.56 & $23,839.78$ & 61.47 & $38,782.77$ & 100 & $+10,287.52$ & +26.53 \\
\hline Cultivation & $2,172.24$ & 14.75 & $18,482.16$ & 89.48 & $12,554.94$ & 85.25 & $14,727.18$ & 100 & -5927.22 & -40.25 \\
\hline Open space & $7,224.22$ & 32.68 & $19,180.32$ & 72.64 & $14,880.8$ & 67.32 & $22,105.02$ & 100 & -4299.52 & -19.45 \\
\hline Shrub & $9,780.19$ & 44.66 & 18857.17 & 65.85 & $12,120.69$ & 55.34 & $21,900.88$ & 100 & -6736.48 & -30.76 \\
\hline Light forest & $10,261.99$ & 57.43 & $13,710.99$ & 57.19 & $7,606.33$ & 42.57 & $17,868.32$ & 100 & -6104.66 & +34.17 \\
\hline Wetland & $1,565.13$ & 11.55 & $2,572.96$ & 62.18 & $11,981.64$ & 88.45 & $13,546.77$ & 100 & +9408.68 & +69.45 \\
\hline Total & $72,504.11$ & 44.39 & $90,839.57$ & 55.61 & $90,845.62$ & 55.61 & $163,349.73$ & 100 & - & - \\
\hline
\end{tabular}

*LULC- Land use/Land cover

Table 5. Proportion of Agricultural Land use Gained and/or Lost between 2000 and 2016 (Data source: Author's image analysis, 2018)

\begin{tabular}{|c|c|c|c|c|c|c|c|c|c|c|}
\hline \multirow[t]{2}{*}{ LULC } & \multicolumn{2}{|c|}{$\begin{array}{l}\text { LULC in } 2000 \text { and } \\
\text { Unchanged in } 2016\end{array}$} & \multicolumn{2}{|c|}{$\begin{array}{l}\text { LULC in } 2000 \text { lost to other } \\
\text { LULC by } 2016\end{array}$} & \multicolumn{2}{|c|}{$\begin{array}{l}\text { LULC in } 2000 \text { gained from } \\
\text { other LULC type by } 2016\end{array}$} & \multicolumn{2}{|c|}{$\begin{array}{c}\text { LULC in } 2016 \\
\text { (unchanged + gained) }\end{array}$} & \multicolumn{2}{|c|}{$\begin{array}{l}\text { Difference of (2000-2016) } \\
\text { LULC gained-lost }\end{array}$} \\
\hline & ha & $\%$ & ha & $\%$ & ha & $\%$ & ha & $\%$ & $\mathrm{Ha}$ & $\%$ \\
\hline Water body & $27,081.22$ & 96.31 & $7,337.57$ & 21.32 & $1,038.84$ & 3.69 & $28,120.06$ & 100 & -6298.73 & +22.40 \\
\hline Build up & $31,816.87$ & 40.35 & $6,965.90$ & 17.96 & $47,043.57$ & 59.65 & $78,860.46$ & 100 & +40077.67 & +50.82 \\
\hline Cultivation & $3,587.52$ & 30.09 & $11,139.66$ & 75.64 & $8,337.04$ & 69.91 & $11,924.56$ & 100 & -2802.62 & -23.50 \\
\hline Open space & $2,707.79$ & 20.19 & $19,397.23$ & 87.75 & $10,702.62$ & 79.81 & $13,410.41$ & 100 & --8694.61 & -64.84 \\
\hline Shrub & $1,996.60$ & 33.65 & $19,904.28$ & 90.88 & $3,937.36$ & 66.35 & $5,933.96$ & 100 & -15966.92 & -269.08 \\
\hline Light forest & 3500.78 & 53.76 & $14,367.54$ & 80.41 & $3,010.8$ & 46.24 & $6,511.58$ & 100 & -11356.74 & -174.41 \\
\hline Wetland & $6,518.51$ & 35.07 & $7,028.26$ & 51.88 & $12,070.17$ & 64.93 & $18,588.68$ & 100 & +5041.91 & +27.12 \\
\hline Total & $77,209.29$ & 47.27 & $86,140.44$ & 52.73 & $86,140.4$ & 52.73 & $163,349.71$ & 100 & - & - \\
\hline
\end{tabular}

*LULC- Land use/Land cover 


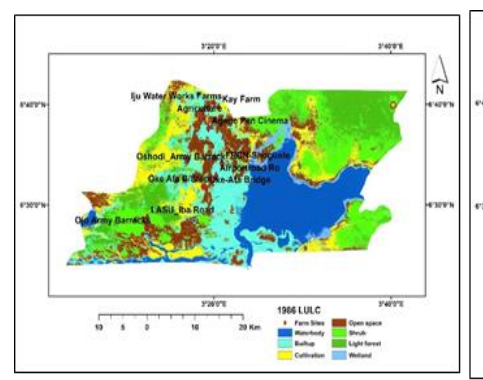

a.

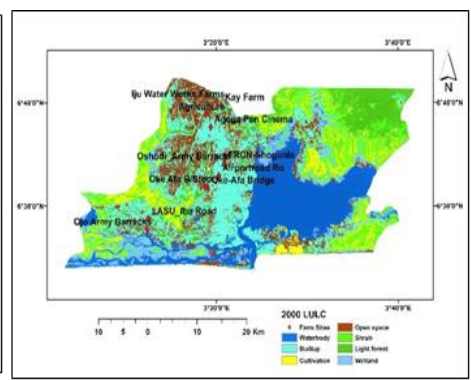

b.

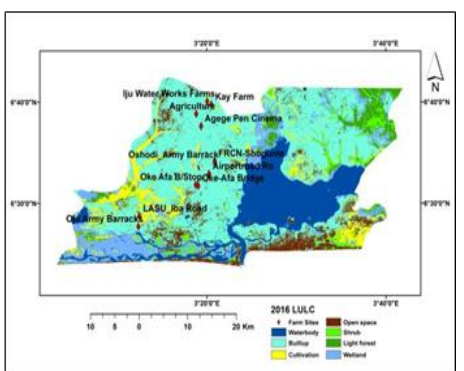

c.

Figure 3. Land use/land cover Map of Metropolitan Lagos 1986, 2000 and 2016 (Source: Author's image analysis, 2018)

\section{Conversion Pattern of Cultivated Lands between 1986 and 2016}

Although urban agriculture is a permanent element of the urban system, its locations within the city may vary over time. Field survey has revealed a form of lease agreement between private and institutional owners of vacant lands with organized farmers group allowing temporary use for longer periods. They may also provide alternative lands (often also on a temporary basis) when these sites are needed for other purposes before the lease ends. The Lagos State Water Corporation at Iju, the Broadcasting Organisation of Nigeria (BON) at Shogunle and Kay Farms at Obawole areas of Lagos state are good field examples of such dynamic urban farms (Awoniran, 2017).

Planning controls have been known to influence farm sizes through the encouragement of development in areas that were once used for farming. Where physical development has been slow and there is less enforcement of controls over development, farm sizes are not affected and agriculture prevails. This situation becomes reversed where development is fast and where controls upon it are strictly enforced. In such cases, sizes of farms tend to be drastically reduced (Nsangu and Redwood, 2009).

Further analysis of agricultural land use change as presented in table 6 and 7 indicated that between 1986 and 2000, 1115.33 ha $(5.40 \%)$ of cultivated lands have reverted to water body, 5651.63 ha $(27.36 \%)$ have been converted to built-up, 4,607.35 ha (22.31\%) to open space, 3,094.16 ha $(14.98 \%)$ to shrub, 1444.45 ha $(6.99 \%)$ to light forest and 2569.22 ha $(12.44 \%)$ to wetland. So also between 2000 and $2016,7.10$ ha $(0.05 \%)$ of cultivated lands had reverted to water body, 5856.03 ha $(39.76 \%)$ have been converted to built-up, 1839.74 ha $(12.49 \%)$ to open space, 746.07 ha $(5.07 \%)$ to shrub, 788.23 ha $(5.35 \%)$ to light forest and 1902.48 ha $(12.92 \%)$ to wetland.

Table 6. Conversion Pattern of Cultivated Lands between 1986 and 2000

(Source: Author's image analysis, 2018)

\begin{tabular}{|c|c|c|c|c|c|c|c|c|c|}
\hline \multicolumn{10}{|c|}{ Land use/Land cover classes of 2000 (ha) } \\
\hline \multirow{9}{*}{ 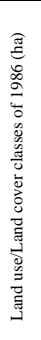 } & LULC & Waterbody & Built-up & Cultivation & Open space & Shrub & Light Forest & Wetland & TOTAL \\
\hline & Waterbody & $\begin{array}{c}26,557.35 \\
85.56 \%\end{array}$ & $\begin{array}{l}1624.76 \\
5.23 \%\end{array}$ & $\begin{array}{c}388.14 \\
1.25\end{array}$ & $\begin{array}{c}1092.43 \\
3.52\end{array}$ & $\begin{array}{l}160.59 \\
0.52 \%\end{array}$ & $\begin{array}{l}21.31 \\
0.07 \%\end{array}$ & $\begin{array}{c}1196.48 \\
3.85 \%\end{array}$ & $\begin{array}{c}31,041.06 \\
100\end{array}$ \\
\hline & Built up & $\begin{array}{l}3159.43 \\
11.09 \%\end{array}$ & $\begin{array}{c}14942.99 \\
52.44 \%\end{array}$ & $\begin{array}{l}1170.34 \\
4.11 \%\end{array}$ & $\begin{array}{l}6114.36 \\
21.46 \%\end{array}$ & $\begin{array}{l}705.24 \\
2.48 \%\end{array}$ & $\begin{array}{c}1217.53 \\
4.27 \%\end{array}$ & $\begin{array}{c}1185.36 \\
4.16 \%\end{array}$ & $\begin{array}{c}28,495.25 \\
100\end{array}$ \\
\hline & Cultivation & $\begin{array}{c}1115.33 \\
5.40 \% \\
\end{array}$ & $\begin{array}{l}5651.63 \\
27.36 \% \\
\end{array}$ & $\begin{array}{c}2,172.24 \\
10.52 \% \\
\end{array}$ & $\begin{array}{l}4607.35 \\
22.31 \% \\
\end{array}$ & $\begin{array}{l}3094.16 \\
14.98 \% \\
\end{array}$ & $\begin{array}{c}1444.45 \\
6.99 \% \\
\end{array}$ & $\begin{array}{l}2569.22 \\
12.44 \% \\
\end{array}$ & $\begin{array}{c}20,654.40 \\
100 \\
\end{array}$ \\
\hline & Open space & $\begin{array}{c}1754.34 \\
6.64 \%\end{array}$ & $\begin{array}{l}9367.87 \\
35.48 \% \\
\end{array}$ & $\begin{array}{c}1209.67 \\
4.58 \% \\
\end{array}$ & $\begin{array}{l}7,224.22 \\
27.36 \% \\
\end{array}$ & $\begin{array}{c}2144.58 \\
8.12 \% \\
\end{array}$ & $\begin{array}{c}1432.68 \\
5.43 \%\end{array}$ & $\begin{array}{l}3271.09 \\
12.39 \% \\
\end{array}$ & $\begin{array}{c}26,404.54 \\
100\end{array}$ \\
\hline & Shrubs & $\begin{array}{l}566.36 \\
1.98 \% \\
\end{array}$ & $\begin{array}{l}4218.88 \\
14.73 \% \\
\end{array}$ & $\begin{array}{l}6117.45 \\
21.36 \% \\
\end{array}$ & $\begin{array}{l}1618.56 \\
5.65 \% \\
\end{array}$ & $\begin{array}{c}9,780.19 \\
34.15 \% \\
\end{array}$ & $\begin{array}{l}3416.31 \\
11.93 \% \\
\end{array}$ & $\begin{array}{l}2919.61 \\
10.19 \% \\
\end{array}$ & $\begin{array}{c}28,637.36 \\
100 \\
\end{array}$ \\
\hline & Light forest & $\begin{array}{l}94.86 \\
0.4 \% \\
\end{array}$ & $\begin{array}{l}2560.22 \\
10.68 \% \\
\end{array}$ & $\begin{array}{l}3564.49 \\
14.87 \% \\
\end{array}$ & $\begin{array}{l}912.72 \\
3.81 \% \\
\end{array}$ & $\begin{array}{l}5738.42 \\
23.94 \% \\
\end{array}$ & $\begin{array}{c}10261.99 \\
42.81 \%\end{array}$ & $\begin{array}{l}840.28 \\
3.51 \% \\
\end{array}$ & $\begin{array}{c}23,972.98 \\
100 \\
\end{array}$ \\
\hline & Wetland & $\begin{array}{l}1170.20 \\
28.28 \% \\
\end{array}$ & $\begin{array}{l}414.96 \\
10.03 \% \\
\end{array}$ & $\begin{array}{c}103.54 \\
2.5 \%\end{array}$ & $\begin{array}{l}534.83 \\
12.92 \% \\
\end{array}$ & $\begin{array}{l}276.11 \\
6.67 \% \\
\end{array}$ & $\begin{array}{l}73.34 \\
1.77 \% \\
\end{array}$ & $\begin{array}{l}1,565.13 \\
37.82 \% \\
\end{array}$ & $\begin{array}{c}4,138.09 \\
100\end{array}$ \\
\hline & TOTAL & $34,418.79$ & $38,782.77$ & $14,727.21$ & $22,105.02$ & $21,900.88$ & $17,868.32$ & $13,546.77$ & 163343.68 \\
\hline
\end{tabular}

*LULC- Land use/Land cover

Drescher (2003) argued that conversion of agricultural land to urban uses is a particular concern, as rapid growth and escalating land values threaten farming on prime soils. Existing farmland 
conversion patterns often discourage farmers from adopting sustainable practices and a long-term perspective on the value of land. At the same time, the close proximity of newly developed residential areas to farms increases public demand for environmentally safe farming practices. Comprehensive new policies to protect prime soils and regulate development are needed. By helping farmers to adopt practices that reduce use of chemicals and conserve scarce resources, sustainable agriculture research and education can play a key role in building public support for agricultural land preservation.

Table 7. Conversion Pattern of Cultivated Lands between 2000 and 2016

(Source: Author's image analysis, 2018)

\begin{tabular}{|c|c|c|c|c|c|c|c|c|c|}
\hline \multirow{14}{*}{ 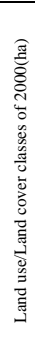 } & \multicolumn{9}{|c|}{ Land use/Land cover classes of 2016 (ha) } \\
\hline & LULC & Water body & Built-up & Cultivation & Open space & Shrub & Light Forest & Wetland & TOTAL \\
\hline & \multirow[t]{2}{*}{ Water body } & $27,081.22$ & 3056.29 & 126.29 & 1150.03 & 143.73 & 83.69 & 2777.54 & 34418.79 \\
\hline & & $78.68 \%$ & $8.88 \%$ & $0.37 \%$ & $3.34 \%$ & $0.42 \%$ & $0.24 \%$ & $8.07 \%$ & 100 \\
\hline & \multirow[t]{2}{*}{ Built up } & 431.82 & $31,816.87$ & 1447.11 & 4345.46 & 381.04 & 2.07 & 358.38 & $38,782.77$ \\
\hline & & $1.11 \%$ & $82.04 \%$ & $3.73 \%$ & $11.21 \%$ & $0.98 \%$ & $0.01 \%$ & $0.92 \%$ & 100 \\
\hline & Cultivation & $\begin{array}{c}7.10 \\
0.05 \%\end{array}$ & $\begin{array}{l}5856.03 \\
39.76 \%\end{array}$ & $\begin{array}{l}3,587.52 \\
24.36 \%\end{array}$ & $\begin{array}{l}1839.74 \\
12.49 \%\end{array}$ & $\begin{array}{l}746.07 \\
5.07 \%\end{array}$ & $\begin{array}{l}788.23 \\
5.35 \%\end{array}$ & $\begin{array}{l}1902.48 \\
12.92 \%\end{array}$ & $\begin{array}{c}14,727.18 \\
100\end{array}$ \\
\hline & Open space & 88.45 & 18326.48 & 317.58 & $2,707.79$ & 278.56 & $\begin{array}{c}1.89 \\
0.01 \%\end{array}$ & 384.27 & $22,105.02$ \\
\hline & \multirow[t]{2}{*}{ Shrubs } & 19.77 & 8696.50 & 4077.59 & 1351.92 & $1,996.60$ & 1496.19 & 4262.31 & $21,900.88$ \\
\hline & & $0.09 \%$ & $39.71 \%$ & $18.62 \%$ & $6.17 \%$ & $9.12 \%$ & $6.83 \%$ & $19.46 \%$ & 100 \\
\hline & Light forest & $\begin{array}{c}2.25 \\
0.01 \%\end{array}$ & $\begin{array}{l}7356.08 \\
41.17 \%\end{array}$ & $\begin{array}{c}1723.69 \\
9.65 \%\end{array}$ & $\begin{array}{c}1164.32 \\
6.52 \%\end{array}$ & $\begin{array}{c}1736.01 \\
9.72 \%\end{array}$ & $\begin{array}{l}3500.78 \\
19.59 \%\end{array}$ & $\begin{array}{l}2385.18 \\
13.35 \%\end{array}$ & $\begin{array}{c}17,868.32 \\
100\end{array}$ \\
\hline & \multirow[t]{2}{*}{ Wetland } & 489.44 & 3752.20 & 644.77 & 851.15 & 651.96 & 638.75 & $6,518.51$ & $13,546.77$ \\
\hline & & $3.61 \%$ & $27.70 \%$ & $4.76 \%$ & $6.28 \%$ & $4.81 \%$ & 4.72 & $48.12 \%$ & 100 \\
\hline & TOTAL & 28120.05 & 78860.45 & 11924.55 & 13410.41 & 5933.97 & 6511.6 & 18588.67 & 163349.7 \\
\hline
\end{tabular}

*LULC- Land use/Land cover

\section{Implications of the Practice of Urban Agriculture for Urban Planning Threatened Food Security}

Sustained conversion of farmland to real estate development in Lagos Metropolis threatens the long-term viability of urban agriculture and by extension food security. Much of the present urban growth in the metropolis is occurring at the expense of urban farmland. As this pattern of growth is likely to continue the land available for urban agriculture in the metropolis may be drastically reduced. Sy et al., (2014) reporting from the city of Dakar, Senegal submited that the present condition of urban agriculture is the outcome of ambiguous land and urban planning policies on the part of authorities. Despite the enormous benefits for individuals and communities, urban agriculture is largely ignored in urban and regional planning (Lovell, 2010). Instead of considering opportunities to preserve farmland or to integrate new production functions into urban environments, agricultural landscapes are often considered by land use planners as areas for future development. Because planners and policy makers are not typically engaged in the production activities of agriculture, they often overlook problems and opportunities within the entire food system. As a result, we see a growing disconnect between urban residents and the agricultural landscapes that sustain them (Pothukuchi, 2004). A community dependent on food resources from distant locations is vulnerable to any unforeseen disasters (natural or otherwise) or disruptions at different levels of the food systems chain from production through processing and transport to distribution centers (Lovell, 2010).

\section{Decreasing Access to Land by Urban Farmers}

One of the greatest constraints to the widespread adoption of urban agriculture is the limited access to land for those who would like to grow food, and the lack of secure of tenure on that land, particularly where the production functions are competing with other uses (such as commercial development) that provide greater profit for the landowner (Redwood, 2009). For example, studies have revealed that many urban farms are established on vacant lots or other underutilized spaces, but without the direct permission or long-term commitment of the land owner or manager. Marginalized groups and minority populations are particularly vulnerable to the problem of land access and security, since they often do not have the means to purchase land (Redwood, 2009; Poor and Brule 2007). Thus urban agriculture as practiced in most cities of developing countries, remain a survivalist enterprise, undertaken by people unable to secure a regular wage employment or access to an 
economic sector of their choice. Consequently, poverty and a desperate attempt to survive are the prime defining features of urban agriculture enterprise (Adeyinka et al., 2006).

\section{CONCLUSION AND RECOMMENDATIONS}

The results of this study has shown that the practice of urban agriculture cut across both male and female gender and is a spatial phenomenon that is prone to change. However, in view of the facts that the land available for urban farming is shrinking deliberate efforts should be made to attenuate this potential threat to food security and sustainable urban growth. This can be done by zoning designated agricultural areas along streams, roads or power lines (buffer zones). This would be a milestone towards official support and more sustainability of this interesting farming system.

Urban agriculture provides an important research opportunity in assessing the suitability of urban land for agricultural functions, based on factors such as soil type, solar access, and proximities to necessary markets and resources. Spatial analysis in Geographic Information Systems (GIS), which has been used to map green infrastructure and extend green networks could offer useful applications for assessing and expanding urban agriculture. Asset mapping, which is a multistakeholder process for action planning and policy design, can be used to describe the physical characteristics of a study site using GIS data including land use land cover Using the results of suitability analysis, land use inventories can be developed to map the suitable land to help increase institutional awareness and political support for urban agriculture.

\section{REFERENCES}

Adereti, F.O., Orji, E.E., \& Ojo, T.F. (2010). Urban Agriculture in Ojo Local Government of Area of Lagos State, Nigeria. In Remi Adeyemo (ed.) Urban Agriculture, Cities and Climate Change Humboldt International Conference, Obafemi Awolowo University Ile-Ife, 138-142.

Adeyinka, S.A., Omisore, E. O., Olawuni, P. O., \& Abegunde, A. A. (2006, October). An evaluation of informal sector activities and urban land use management in south western Nigeria. In XXIII FIG Congress Munich: Shaping the Change, Germany, October 8-13, 2006.

Appeaning Addo, K. (2010). Urban and peri-urban agriculture in developing countries studied using remote sensing and in situ methods. Remote Sensing, 2(2), 497-513.

Afrane, Y.A., Keraita, N., \& Danso, G.K. (2002). Farming systems in (Peri) Urban Accra, Ghana: Special focus on its Profitability, Wastewater use and added Malaria risks. Report submitted to the International Water Management Institute, Ghana.

Aina, O.S., Oladapo, A., Adebosin, W.G., \& Ajijola, S. (2012). Urban livelihood: urban agriculture implication in food security, a case study of Ibadan Metropolis. Journal of Applied Phytotechnology in Environmental Sanitation, 1(4), 155-161.

Ajadi, B.S., Adeniyi, A., \& Afolabi, M.T. (2011). Impact of climate on urban agriculture: case study of Ilorin City, Nigeria. Global Journal of Human Social Science, 11(1), 12.

Akinmoladun, O.I., \& Adejumo, O.T. (2011). Urban agriculture in metropolitan Lagos: An inventory of potential land and water resources. Journal of Geography and Regional Planning, 4(1), 9-19.

Arturo, P.V. \& Simon, A. (2003). A Methodological Review of Researchinto Urban Agriculture. In Wietse B. and Wilfrid H., eds. Annotated Bibliography on Urban Agriculture Sida, ETC, Netherlands, 618-629.

Awoniran, D.R. (2017). Spatio-temporal Analysis of Urban Agricultural Practice in Lagos Metropolis. An M.Phil Thesis submitted to the Department of Urban and regional Planning, Obafemi Awolowo University, Ile-Ife, Nigeria.

Bellwood-Howard, I., Häring, V., Karg, H., Roessler, R., Schlesinger, J., \& Shakya, M. (2015). Characteristics of urban and peri-urban agriculture in West Africa: results of an exploratory survey conducted in Tamale (Ghana) and Ouagadougou (Burkina Faso) (Vol. 163). International Water Management Institute (IWMI).

Nsangu, C.A., \& Redwood, M. (2009). Urban agriculture and physical planning: a case study of Zaria, Nigeria. Agriculture in urban planning: Generating livelihoods and food security, 217-234.

Drescher, A.W. (2003). Perspectives of the Urbanizations Process. Discussion Paper, Food Africa Internet Conference, NRI.

Drechsel, P., \& Dongus, S. (2010). Dynamics and sustainability of urban agriculture: examples from sub-Saharan Africa. Sustainability Science, 5(1), 69-78.

Ekanade, O. (1985). The Impact of Cocoa Cultivation on Soil Properties in South Western Nigeria. Unpublished Ph. D Thesis, University of Ife, 305 .

Enaruvbe, G.O., \& Atedhor, G.O. (2015). Spatial analysis of agricultural landuse change in Asaba, Southern Nigeria. Ife Journal of Science, 17(1), 65-74. 
Faruqui, N.I., Niang, S., \& Redwood, M. (2004). Untreated Wastewater Use in Market Gardens: A Case Study of Dakar, Senegal. In Scott, C.A, Faraqui, N.I and Rashid-Sally, L (eds). Wastewater use in Irrigaed Agriculture, Confronting the Livelihoods and EnvironmentalRealities. IDRC CRBI Publishing. pg 113-125.

Duressa, T.F. (2007). Livelihood dependence on urban agriculture in Addis Ababa, Ethiopia.

Foeken, D. (2013). The role of urban agriculture in the development of middle-sized towns: Cases from East Africa. Journal of Geography and Regional Planning, 6(3), 117-131.

Islam, R., \& Siwar, C. (2012). The Analysis of Urban Agriculture Development in Malaysia. Advances in Environmental Biology, 6(3), 1068-1078.

Komolafe, A.A., Adegboyega, S.A., Anifowose, A.Y.B., Akinluyi, F.O., \& Awoniran, D.R. (2014). Airpollution and climate change in Lagos, Nigeria: Needs for proactive approaches to risk management and adaptation. American Journal of Environmental Sciences 10 (4), 412-423.

Losada, H., Martínez, H., Vieyra, J., Pealing, R., Zavala, R., \& Cortés, J. (1998). Urban agriculture in the metropolitan zone of Mexico City: changes over time in urban, suburban and peri-urban areas. Environment and urbanization, 10(2), 37-54.

Lovell, S.T. (2010). Multifunctional urban agriculture for sustainable land use planning in the United States. Sustainability, 2(8), 2499-2522.

Mougeot, L.J. (2006). Growing better cities: Urban agriculture for sustainable development. IDRC, International Development Research Centre, Ottawa.

Mougeout, L.J.A. (2000). Urban Agriculture, Definition, Presence, Potentials and Risks and Policy Challenges. IDRC, Cities Feeding People Series. Report 31.

Moustier, P. (1999). Definitions and boundaries of peri-urban agriculture in sub-saharan Africa. Peri-Urban Agriculture in Sub-Saharan African, 29-42.

Ogunbajo, M.I. (2005). Environmental Assessment Study for the Lagos State Water Corporation under the World Bank Assisted Project Preparation Facility for the National Water Rehabilitation Project.

Omisore, E.O., \& Olaleye, D.O. (2011). Planning Authority Restriction on Urban Agriculture in Urban Planning. In Report of DELPHE Project 758 Urban Planning and Urban Agriculture StakeholdersSensitization Workshop; Veronica A.O. (eds), IART, Ibadan.

Pothukuchi, K. (2004). Community food assessment: A first step in planning for community food security. Journal of Planning Education and Research, 23(4), 356-377.

Poor, P.J., \& Brule, R. (2007). An investigation of the socio-economic aspects of open space and agricultural land preservation. Journal of sustainable agriculture, 30(3), 165-176.

Redwood, M. (2009). Urban Agriculture in urban planning: generating livelihoods and food security. London, United Kingdom: Earthscan and the International Development Research Centre (IDRC).

Salau, E.S., \& Attah, A.J. (2012). A socio-economic analysis of urban agriculture in Nassarawa State, Nigeria. Production Agriculture and Technology, Nassarawa State University. Keffi Journal, 8(1), 17-29.

Smit, J., Nasr, J., \& Ratta, A. (2001). Urban Agriculture: Food, Jobs, and Sustainable Cities. The Urban Agriculture Network. Inc., New York, NY.

Sy, M., Khouma, M., Ndong, M.S.G., Badiane, N.Y., Niang, Y., Diagne, M.O., \& Diop, O. (2014). Renforcer la résilience des systèmes agricoles urbains: Évaluer l'agriculture urbaine et périurbaine à Dakar, Sénégal. [Padgham, J. et J. Jabbour.

Sy, M., Khouma, M., Diagne, M.O., Dial, M.L., Diop, O., Niang, I., Badiane, N.Y., Niang, Y., \& Ndong, M.S.G. (2014). Building Urban Resilience: Assessing Urban and Peri-urban Agriculture in Dakar, Senegal [Renforcer la résilience des systèmes agricoles urbains: Évaluer l'agriculture urbaine et périurbaine à Dakar, Sénégal]. Padgham, J. and J. Jabbour (eds.). United Nations Environment Programme (UNEP), Nairobi, Kenya.

Veenhuizen RV. (2006). Cities Farming for the Future: Urban Agriculture for Green and Productive Cities. (C) Resource Centres on Urban Agriculture and Food Security (RUAF) Foundation.

Veenhuizen, R., \& Danso, G.K. (2007). Profitability and sustainability of urban and peri-urban agriculture. Agricultural Management Marketing and Finance occasional Paper 19, pp 109. FAO 2007.

Submitted:

June 12, 2019
Revised:

December 26, 2019
Accepted and published online June 03, 2020 